\title{
PENGARUH TRAY KARTON, KAYU DAN KAWAT TERHADAP KUALITAS TELUR AYAM ISA BROWN YANG DISIMPAN PADA SUHU KAMAR
}

\author{
WIRAPARTHA, M., K. A. WIYANA, G. A. M. KRISTINA DEWI, DAN I W. WIJANA \\ Fakultas Peternakan Universitas Udayana, Denpasar \\ e-mail: wiraparthaunud@yahoo.co.id
}

\begin{abstract}
ABSTRAK
Tujuan penelitian ini adalah untuk mengetahui pengaruh bahan tray karton,kayu, kawat untuk menyimpan telur ayam Isa Brown pada suhu kamar selama 28 hari. Metode yang digunakan dalam penelitian ini adalah Rancangan Acak Lengkap (RAL) dengan 3 perlakuan (karton, kayu , kawat) dengan 6 ulangan dan setiap ulangan terdiri dari 10 butir. Variabel yang diamati baik eksterior dan interior telur, Haugh Unit dan kandungan nutrisi telur. Hasil penelitian menunjukkan bahwa perlakuan material tray karton, kayu, kawat tidak berpengaruh nyata $(\mathrm{P}>0,05)$ terhadap kualitas eksterior telur, sedangkan perlakuan dengan kayu dan kawat berpengaruh nyata (P $<0,05)$ terhadap $\mathrm{pH}$, Haugh Unit dan kandungan protein dan lemak telur dibandingkan dengan tray karton. Dari hasil penelitian dapat disimpulkan material tray karton, kayu , kawat tidak mempengaruhi kualitas eksterior telur, tetapi tray kayu dan kawat mempengaruhi kualitas interior pH, Haugh Unit, dan kandungan nutrisi protein dan lemak telur ayam Isa Brown disimpan pada suhu kamar selama 28 hari.
\end{abstract}

Kata kunci: karton, kualitas, kayu, kawat, telur

\section{EFFECT OF PLASTIC, CARTON, AND WIRE TRAY MATERIALS TO ISA BROWN EGGS QUALITY TO STORE AT ROOM TEMPERATURE}

\begin{abstract}
The aim of this research is to know the effect of carton, wood, wire tray materials to Isa Brown eggs quality to store at room temperature for 28 days. The method used in this study was Completely Randomized Design (CRD) with 3 treatment (carton, wood, and wire) with 6 replications and each replication consisted of 10 eggs. Variables observed both exterior and interior, Hough Unit and egg nutrient content. The result showed that plastic, carton, wire material had no significant effect $(\mathrm{P}>0$,05) on egg exterior quality, while treatment with wood and wire significantly $(\mathrm{P}<0,05)$ to $\mathrm{pH}$, Hough Unit, protein and fat nutrient content, compared to carton tray. From the research results can be concluded the materials of carton, wood, wire tray does not affect the exterior quality of the egg, but the material of wood and wire tray affect the interior quality of $\mathrm{pH}, \mathrm{Haugh}$ Unit, protein and fat nutritional content Isa Brown eggs stored at room temperature for 28 days.
\end{abstract}

Keywords: carton, eggs quality, plastic, stored, wire

\section{PENDAHULUAN}

Peternakan ayam ras petelur dewasa ini sangat berkembang di Indonesia, berkembang dan dipasarkan untuk memenuhi kebutuhan protein hewani masyarakat. Telur yang dihasilkan dipasarkan di pasarpasar tradisional ataupun di swalayan-swalayan, mini mart tergantung dari manajemen pemeliharaan serta biosekuriti kandang yang baik dari produsen telur. Faktor lainnya sangat dipengaruhi pemberian ransum yang seimbang antara protein dan energy. sesuai dengan hasil penelitian Dewi (2011) bahwa sesuai dengan Dewi (2011) bahwa ukuran (bobot) telur, jumlah telur , produksi harian (\% HD), kuning telur yang tinggi meningkat sejalan dengan peningkatan protein dan energi dalam ransum pada ayam kampung..

Kualits telur yang dijual dipasarkan di pasar tradisional di Pasar Badung, Denpasar, Bali sangat bervariasi karena telur yang dijual oleh pedagangpedagang menggunakan tempat atau wadah dari bahan -bahan yang berbeda-beda yaitu tray dari karton, kawat dan kayu. Perbedaan bahan penyimpan telur di berbagai tempat penjualan sangat berpengaruh terhadap 
kualitas telur yang dihasilkan dan mempengaruhi penerimaan terhadap telur yang dibeli oleh konsumen. Penggunaan tempat penyimpanan telur menggunakan wadah bahan yang berbeda memengaruhi kualitas telur yang dipasarkan. Menurut Stadelman dan Cotteril (1973) kualitas telur adalah kumpulan ciriciri telur yang mempengaruhi selera konsumen dan merupakan faktor menentukan derajat kesempurnaan, penerimaan konsumen dari produk telur baik kualitas luar (eksternal) dan kualitas dalam (internal).

Menurut SNI 01-3926-2008 (BSN, 2008) bahwa indek putih telur segar berkisar antara 0,050-0,174 $\mathrm{mm}$. Semakin tua umur atau lama umur telur maka diameter putih telur akan semakin lebar sehingga indeks putih telur akan semakin kecil. Perubahan putih telur disebabkan oleh pertukaran gas antara udara luar dengan isi telur melalui pori-pori kerabang telur dan penguapan air akibat dari lama penyimpanan, suhu, kelembaban, dan porositas kerabang telur (Yuanta, 2010). Hasil penelitian Wirapartha et al. (2015) mendapatkan telur yang disimpan dalam suhu kamar sampai 21 hari masih menghasilkan nilai skor kualitas/ grade B. Selanjutnya pemasaran telur ayam yang ada di pasar belum diketahui kualitas baik eksterior maupun interiornya. Dimana pada bagian luar akan terlihat masih adanya bagian kulit telur yang kotor dan kurang bersih. Hal ini akan berpengaruh pada penerimaan masyarakat.

Kerusakan pada telur ayam ras dapat terjadi secara fisik, kimia maupun biologi sehingga terjadi perubahan selama masa ditelurkan sampai dipasarkan. Diperlukan wadah /tempat untuk membawa telur pada transportasi dijalan, dan juga pada waktu di jual dipasar-pasar dalam proses penyimpanan (Haryanto, 2007). Hasil penelitian Wirapartha et al. (2016) mendapatkan kualitas telur yang dipasarkan di Pasar Badung memiliki kualitas baik fisik maupun mikrobiologis lebih rendah dari pasar Kereneng dan pasar Sanglah secara signifikan masih memenuhi standar SNI sampai grade B. Sehingga telur yang dipasarkan masih layak dikonsumsi. Untuk mengetahui pengaruh berbagai bahan/wadah untuk menyimpan telur yang dipasarkan maka telah dilakukan penelitian mengenai pengaruh tray karton, kayu, dan kawat terhadap kualitas telur ayam Isa Brown yang disimpan pada suhu kamar.

\section{MATERI DAN METODE}

\section{Tempat dan Lama Penelitian}

Penelitian dilaksanakan di Pasar Badung, Kota Denpasar, Bali, analisis dilakukan di Laboratorium Nutrisi dan Pakan Ternak, Laboratorium Teknologi Hasil Ternak, Laboratorium Ternak Unggas, Fakultas Peternakan Universitas Udayana selama 3 bulan.

\section{Rancangan Percobaan}

Rancangan penelitian yang digunakan dalam penelitian ini adalah rancangan acak lengkap (RAL) dengan tiga perlakuan bahan yaitu kawat, karton, dan kayu dan enam ulangan dan setiap ulangan terdiri dari 10 butir telur, total telur yang digunakan sebanyak 180 butir.

\section{Pengambilan dan Penyiapan Sampel}

Sampel telur ayam ras diambil secara bersamaan dari pedagang telur yang berada di Pasar Badung, sampel telur diambil dan ditempatkan dalam wadah bahan dari kawat, karton dan kayu sesuai rancangan. Setelah 28 hari disimpan pada suhu ruangan, telur dibawa ke laboratorium untuk dianalisis baik eksterior maupun interior. Alat yang digunakan pada penelitian ini penggaris, micrometer, jangka sorong , $\mathrm{pH}$ meter, dan Egg Multi Tester (EMT) 7300.

Variabel yang Diamati: a. kualitas telur eksterior (berat telur, kebersihan kerabang telur, permukaan kulit telur, indeks telur); b. kualitas interior ( $\mathrm{pH}$, tebal kerabang, berat kerabang, warna kuning telur, Haugh Unit (HU), dan nutrisi dari telur.

\section{Analisis Data}

Data yang dihasilkan dianalisis dengan sidik ragam (Anova) menggunakan rancangan acak lengkap (RAL) dan apabila terdapat berbeda nyata antar perlakuan dilanjutkan dengan uji Duncan't (Sastrosupadi, 2000).

\section{HASIL DAN PEMBAHASAN}

\section{Pengaruh Perlakuan Terhadap Eksterior Telur Penyimpanan selama 28 Hari}

Pengaruh penyimpanan telur ayam ras pada tempat/ wadah di Pasar Badung dengan menggunakan karton, kayu, dan kawat dapat dilihat pada Tabel 1. Hasil dari pengamatan variabel eksterior terlihat berat telur dari tempat penyimpanan masing-masing sebesar 59,48 g; $59,21 \mathrm{~g}$ dan 58,89 g yang disimpan selama 4 minggu atau 28 hari secara statistik tidak berbeda nyata $(\mathrm{P}>0,05)$.

Rataan lebar telur, panjang telur dan indek telur yang mendapat perlakuan karton, kayu dan kawat secara statistik tidak berbeda nyata $(\mathrm{P}>0,05)$. Ketiga perlakuan diperoleh permukaan telur yang licin serta bentuk telur yang lonjong (Tabel 1).

\section{Pengaruh Perlakuan Terhadap Interior Telur Penyimpanan 28 Hari}

Bagian interior telur ayam ras yang diamati setelah mendapat perlakuan penyimpanan menggunakan bahan yang berbeda dapat dilihat pada Tabel 1. Telur yang disimpan selama 28 hari memiliki tebal kulit berturut-turut $0,416 \mathrm{~mm}, 0,418 \mathrm{~mm}$, dan $0,420 \mathrm{~mm}$ 
Tabel 1. Pengaruh perlakuan terhadap eksterior, interior dan nutrisi telur ayam ras yang disimpan 28 hari

\begin{tabular}{|c|c|c|c|c|}
\hline \multirow{2}{*}{ Variabel } & \multicolumn{3}{|c|}{ Perlakuan } & \multirow{2}{*}{ SEM $^{1)}$} \\
\hline & Karton & Kayu & Kawat & \\
\hline \multicolumn{5}{|l|}{ Eksterior } \\
\hline Berat telur (g) & $59,48^{\mathrm{a} 2)}$ & $59,21^{a}$ & $\left.58,89^{a} 2\right)$ & 0,94 \\
\hline Lebar telur $(\mathrm{cm})$ & $4,44^{a}$ & $4,47 a$ & $4,51^{\mathrm{a}}$ & 0,081 \\
\hline Panjang (cm) & $56,57^{\mathrm{a}}$ & $56,22^{a}$ & $55,98^{\mathrm{a}}$ & 0,18 \\
\hline Indeks telur & $79,89^{a}$ & $79,26^{a}$ & $79,23^{a}$ & 0,91 \\
\hline Kebersihan kerabang & Bersih & Bersih & Bersih & \\
\hline Permukaan & Licin & Licin & Licin & \\
\hline Bentuk telur & Lonjong & Lonjong & Lonjong & \\
\hline \multicolumn{5}{|l|}{ Interior } \\
\hline Tebal kerabang & $0,412^{\mathrm{a}}$ & $0,418^{a}$ & $0,420^{a}$ & 0,033 \\
\hline Berat kerabang & $8,08^{a}$ & $8,40^{\mathrm{a}}$ & $8,43^{a}$ & 0,11 \\
\hline Warna kuning telur & $7,18^{\mathrm{a}}$ & $8,17^{b}$ & $7,87^{\mathrm{ab}}$ & 0,15 \\
\hline $\mathrm{pH}$ & $7,04^{b}$ & $8,72^{\mathrm{a}}$ & $8,50^{a}$ & 0,064 \\
\hline Haugh Unit (HU) & $40,97^{a}$ & $41,91^{a}$ & $39,69^{a}$ & 3,99 \\
\hline Grade & B & B & B & \\
\hline Protein(\%) & $9,45^{a}$ & $7,53^{b}$ & $6,71^{b}$ & 0,04 \\
\hline Lemak (\%) & $8,65^{a}$ & $6,66^{\mathrm{b}}$ & $6,95^{\mathrm{b}}$ & 0,10 \\
\hline
\end{tabular}

secara statistik tidak berbeda nyata $(\mathrm{P}>0,05)$. Berat kerabang telur diperoleh lebih kecil pada perlakuan karton sebesar 8,08 g, meningkat perlakuan kayu sebesar 7,89 g dan 7,90 g pada tempat menggunakan kawat secara statistik tidak berbeda nyata $(\mathrm{P}>0,05)$. Pengaruh perlakuan tempat penyimpanan terhadap warna kuning telur yang diukur menggunakan Yolk Colour Fan berkisar 8,40-8,92. Warna kuning telur tertinggi diperoleh pada penyimpanan dengan karton dan diikuti oleh penyimpanan menggunakan kayu dan kawat. Warna kuning telur ditentukan oleh banyak faktor seperti lingkungan dan genetik. Faktor yang paling dominan mempengaruhi adalah pakan. Sebagaimana dikatakan oleh Sudaryani (2003) bahwa warna kuning telur yang baik berkisar 9-12.

Rataan $\mathrm{pH}$ dari telur ayam ras yang mendapat perlakuan dari penyimpanan menggunakan karton sebesar 7,04, kayu sebesar 8,72 dan kawat sebesar 8,50 berbeda nyata secara statistik $(\mathrm{P}<0,05)$. Semakin lama telur disimpan mengakibatkan $\mathrm{pH}$ telur semakin meningkat. Akibat kenaikan $\mathrm{pH}$ mengakibatkan putih telur menjadi semakin encer karena hilangnya $\mathrm{CO}_{2}$ melalui kerabang telur mengakibatkan konsentrasi ion bikarbonat pada putih telur menurun dan merusak sistim buffer. Sehingga $\mathrm{pH}$ telur menjadi naik dan putih telur menjadi basa (Jazil et al., 2013) dan Cornelia (2014), juga serabut ovomucin (memberikan tekstur kental). Faktor lingkungan yang berpengaruh adalah penyimpanan menggunakan bahan kawat dan kayu lebih rendah dari bahan karton. Bahan tempat penyimpanan memberikan rataan Haugh Unit sebesar 41,97 pada karton, 40,91 untuk kayu dan 39,69 untuk kawat grade telur yang diteliti berada pada grade B. Lama penyimpanan mempengaruhi Haugh Unit (HU) yang mengakibatkan nilainya rendah, dan dari grade telur sesuai dengan Sudaryani (2003) dan Yuanta (2010) memiliki skor B karena berada antara 31-54. Telur busuk nilainya di bawah 50 sehingga tidak layak untuk dikonsumsi (Buckle et al., 1987).

Kandungan gizi sebutir telur dengan berat 50 gram terdiri dari protein 6,3 gram, karbohidrat o,6 gram, lemak 5 gram, vitamin dan mineral (Sudaryani, 2003). Penyimpanan menggunakan tempat penyimpanan kayu dan kawat lebih rendah kandungan proten dan lemak dibanding tempat terbuat dari karton berbeda nyata $(\mathrm{P}<0,05)$. Kandungan protein telur berkisar antara 6,71-9,45\% dan lemak sebesar 6,66-8,64\%. Waktu penyimpanan yang semakin lama menyebabkan kesempatan bakteri untuk memetabolisme protein telur menjadi semakin besar sehingga menyebabkan semakin besar pula jumlah protein yang dapat diuraikan bakteri menjadi unit-unit yang lebih sederhana. Penguraian protein telur oleh bakteri untuk metabolismenya menyebabkan terjadinya penurunan kadar protein (Buckle et al., 1987).

\section{SIMPULAN}

Dari hasil penelitian dapat disimpulkan wadah dari plastik, karton, dan kawat tidak memengaruhi kualitas eksterior telur, tetapi wadah dari plastik dan kawat mempengaruhi kualitas interior terhadap pH, Haugh Unit, dan kandungan nutrisi protein, lemak telur ayam ras yang disimpan selama 28 hari.

\section{UCAPAN TERIMAKASIH}

Terimakasih ke pada Rektor Universitas Udayana, Ketua Lembaga Penelitian dan Pengabdian Masyarakat dan Dekan Fakultas Peternakan Universitas Udayana atas dana Hibah Unggulan Program Studi Fakultas Peternakan yang diberikan dan tak lupa pula kami ucapakan banyak terimakasih atas bantuan temanteman peneliti dan mahasiswa serta laboran yang telah membantu.

\section{DAFTAR PUSTAKA}

BSN (Badan Standar Nasional). 2008. Indek Putih Telur Segar. 01-3926-2008. Standar Nasional Indonesia, Jakarta.

Buckle, K. A. R. A. Edward, G. H. Fleet and M. Wooton. 1987. Ilmu Pangan. Universitas Indonesia, Jakarta.

Cornelia, A., I K. Suada, dan M. D. Rudyanto. 2014. Per- 
bedaan Daya Simpan Telutr Ayam Ras yang Dicelupkan dan Tanpa Dicelupkan Larutan Kulit Manggis. Indonesia Medicus Veterinus 3(2): 112 - 119. ISSN: 2301-7848.

Dewi, G. A. M. K., I G. Mahardika, I K. Sumadi, dan I M. Suasta. 2011. Peningkatan Produktivitas Ayam Kampung Melalui Penentuan Kebutuhan Energi dan Protein Pakan. Laporan Penelitian Hibah Bersaing.

Haryanto, R. 2007. Pengaruh Wadah dan Lama Penyimpanan terhadap Kualitas Telur Ayam Ras. Skripsi. Makasar.

Jazil, N., A. Hintono, dan S. Mulyani. 2013. Penurunan Kualitas Telur Ayam Ras dengan Intensitas Warna Coklat Kerabang Berbeda selama Penyimpanan. Jurnal Aplikasi Teknologi Pangan Vol.2 no 1.

Sastrosupadi, A. 2000. Rancangan Percobaan Praktis Bidang Pertanian. Edisi Revisi. Penerbit Kanisius, Yogyakarta.
Stadelman, W. J. and O. J. Cotterill, 1973.Egg Science and Technology.Mac Millan Publishers, UK.

Sudaryani, T. 2003. Kualitas Telur. Penebar Swadaya,Jakarta. Wirapartha, M, K. A. Wiyana, G. A. M. K. Dewi. 2015. Pengaruh Lama Penyimpanan terhadap Kualitas dan Kandungan Nutrisi Telur Ayam Kampung dengan Pemeliharaan Ekstensif. Prosiding Senastek, Universitas Udayana.

Wirapartha, M, K. A. Wiyana, G. A. M. K. Dewi. 2016. Kualitas Fisik dan Mirobiologis Telur Ayam Kampung yang Dipasarkan di Pasar Badung, Pasar Kereneng dan Pasar Sanglah. Prosiding Senastek, Universitas Udayana.2016.

Yuanta, T. 2010. Telur dan Kualitas Telur. Gadjah Mada University Press. 